\title{
Market Regulation, Labor Policies and the Wage-Productivity Gap
}

\author{
Riccardo Tilli, Andrea Rollin \\ Department of Economics and Law, Sapienza University of Rome, Rome, Italy \\ Email: riccardo.tilli@uniroma1.it
}

How to cite this paper: Tilli, R. and Rollin, A. (2017) Market Regulation, Labor Policies and the Wage-Productivity Gap. Modern Economy, 8, 397-405.

https://doi.org/10.4236/me.2017.83029

Received: February 2, 2017

Accepted: March 4, 2017

Published: March 7, 2017

Copyright $\odot 2017$ by authors and Scientific Research Publishing Inc. This work is licensed under the Creative Commons Attribution International License (CC BY 4.0).

http://creativecommons.org/licenses/by/4.0/

\begin{abstract}
This paper proposes an empirical analysis about the influence of some institutional factors (taxation, active and passive labor market policies, labor and goods market regulation and unions' participation) on the component of the wage growth not explained by the productivity growth (WP gap, thereafter). We consider a 14 OECD countries Panel Data over the period 1983-2003, using four different estimations: fixed effects vector decomposition (FEVD), fixed effects (FE), random effects (RE) and feasible general least square (FGLS). Results for all estimations show that the WP gap is affected by tax wedge, active labor market policies, employment protection for temporary workers and union density, while product market regulation and passive labor market policies do not play a significant role.
\end{abstract}

\section{Keywords}

Taxation, Labor Market Policies, Labor and Goods Market Regulation, Wage, Productivity

\section{Introduction}

Starting from the Eighties, Italy and most of the European countries have been involved in significant reforms in labor and goods market, aiming to modify the mechanism of price formation, the degree of labor and product market rigidity, the incidence of taxation and the bargaining process between unions and firms. In this paper we analyze from the empirical point of view the effects of these institutional changes on the share of wage growth not explained by the productivity growth (WP gap, thereafter).

Some authors focus their attention on the role of some institutional factors affecting productivity. [1] analyzes the differences between productivity growth in the US and in the European Union. Looking at their results, the US shows a 
higher level of productivity growth with respect to the EU, because they achieved ICT investment with more intensity than European countries. In particular, the United States performs high level of ICT investment because of the decrease of the mark-up, caused by the deregulation in the product market. [2] shows that reforms towards a more competitive product market produce more positive effect on GDP and productivity growth than in a rigid labor market. [3] proposes an empirical investigation about the effects of labor market deregulation on productivity growth. They highlight that a deregulation not accompanied by the support for dismissal workers, could affect negatively productivity and GDP growth.

[4] considers a OECD panel over the period 1985-2007 finding that wages grows more than productivity only for permanent workers, while temporary workers show the opposite behavior because their lower bargaining power. The increase of the share of temporary workers in most of the European countries can thus explain the increase of the wage productivity gap.

[5] evaluates the effects on productivity of a deregulation policy on good and labor market. The authors find that, through their impact on production prices and wages, a liberalization in the product and labor market can produce positive effects on multifactor productivity over the years.

[6] studies the relationship between wage and productivity taking into account the wage setting process in different countries. His results show that in countries with high collective bargaining coverage wage follows productivity, while in countries like U.S. a decentralize system of wage bargaining is able to explain a causality in the opposite direction ${ }^{1}$. [8] sets up a model with monopolistic competition in the goods market, entry costs and Nash bargaining structure. They show that a more flexible labor market and a more competitive product market bring about, in the medium run, productivity growth with positive effects on wages and on the employment rate.

The paper is structured as follow: The next section describes the data, while section 3 explains methodology. Section 4 displays and discusses the results. Section 5 concludes.

\section{Data}

We take our sample from the [9] dataset. The Panel comprises 14 countries over the period 1983-2003.

The dependent variable, the WP gap, is the residual series of the OLS regression between the growth rate of real wages per employee and the labor productivity growth.

The independent variables are: 1) the average unemployment benefit replacement rate $(\operatorname{arr}) ; 2)$ the initial unemployment benefit replacement rate (rrI);3) the tax wedge (labortax); 4) the unions density (undens); 5) the union coverage in the collective bargaining (uncovcm); 6) the product market regulation index $(p m r)$; 7) the employment protection legislation index for temporary workers

\footnotetext{
${ }^{1}$ See also [7].
} 
(eplt) and for permanent workers (eplr); 8) four components of active labor market policies: Training (almptrain), measures for youth unemployment (almpyouth), employment subsidies (almpempl) and spending for public employment services (almppes) ${ }^{2}$.

\section{Methodology}

We use four methods: Fixed effect vector decomposition (FEVD), fixed effects (FE), random effects (RE) and feasible general least square (FGLS). The first one is a new estimator and it is described in detail, the other three estimators are traditional and widely used in the literature.

The FEVD, developed for the first time by [10] and [11], is able to take into account time invariant variables and rarely changing variables, like the institutions and at the same time to consider the fixed effects ${ }^{3}$.

This method consists in three passages. We start from the following basic Equation:

$$
Y_{i t}=\alpha+\sum_{k=1}^{K} \beta_{k} x_{k i t}+\sum_{m=1}^{M} \gamma_{m} z_{m i}+u_{i}+\varepsilon_{i t}
$$

where the $x$ variables are time variant, the $z$ variables are time invariant, $u$ represents the fixed effects-the unit specific effects-and $\varepsilon$ the error term.

The first step of the FEVD procedure-the estimate of a standard fixed effects model-is making through a fixed effects transformation over $T$. Now, we write a first averaging Equation:

$$
\bar{Y}_{i}=\sum_{k=1}^{K} \beta_{k} \bar{x}_{k i}+\sum_{m=1}^{M} \gamma_{m} z_{m i}+\bar{e}_{i}+u_{i}
$$

where $\bar{Y}_{i}, \bar{x}_{i}$ and $\bar{e}_{i}$ are respectively:

$\bar{Y}_{i}=\frac{1}{T} \sum_{t=1}^{T} Y_{i t} ; \bar{x}_{i}=\frac{1}{T} \sum_{t=1}^{T} x_{i t} ; \bar{e}_{i}=\frac{1}{T} \sum_{t=1}^{T} e_{i t}$ and $e$ are the residuals. The objective of the transformation is to eliminate of the time invariant variables and the fixed effects. To reach these objectives we subtract Equation (2) from equation (1). Simplifying and calling $\ddot{Y}_{i t}=Y_{i t}-\bar{Y}_{i}, \ddot{x}_{k i t}=x_{k i}, \ddot{e}_{i}=e_{i}-\bar{e}_{i}$ we obtain:

$$
\ddot{Y}_{i t}=\beta_{k} \sum_{k=1}^{K} \ddot{X}_{k i t}+\ddot{e}_{i}
$$

while the pooled OLS fixed effects estimate is:

$$
\hat{u}_{i}=\bar{Y}_{i t}-\sum_{k=1}^{K} \beta_{k}^{F E} \bar{X}-\bar{e}_{i}
$$

The estimate includes the unobserved fixed effects.

In the second stage, we regress the estimate unit specific effects, obtained in the first step, on the time invariant variables in order to divide what is explained by the slow changing variables and what is unexplained.

The estimated fixed effects with the time invariant is described by the following Equation:

$$
\hat{u}_{i}=\sum_{m=1}^{M} \gamma_{m} z_{m i}+h_{i}
$$

where $h_{i}$ is the term that represent the unexplained part while the explained ${ }^{2}$ For details see appendix.

${ }^{3}$ See also [2] [12] [13] [14]. 
part is described by the time invariant variables $Z_{m i}$. The aim of this passage is to estimate $h_{i}$

$$
h_{i}=\hat{u}_{i}-\sum_{m=1}^{M} \gamma_{m} z_{m i}
$$

In the third step the full model is estimated, using pooled OLS method, as in the first passage, but without the unit effects and with $h_{i}$ :

$$
Y_{i t}=\alpha+\sum_{k=1}^{K} \beta_{k} x_{k i t}+\sum_{m=1}^{M} \gamma_{m} z_{m i}+\delta h_{i}+\varepsilon_{i t}
$$

From Equation (7), by construction, $h_{i}$ is no longer correlated with the vector of the time invariant variables.

The fixed effects (FE) analysis, with respect to FEVD, does not take into account the time invariant variables. Thus, Equation (1) becomes:

$$
Y_{i t}=\alpha+\sum_{k=1}^{K} \beta_{k} x_{k i t}+u_{i}+\varepsilon_{i t}
$$

where $u_{i}$ represents the time independent fixed effects term. The $u_{i}$ is a vector and it identifies an unobserved effect for each entity considered in our sample countries. This term could be correlated with the independent variables but it must not be correlated with the error term otherwise the estimator could be inconsistent.

The random effects (RE) model is similar to FE model but the effects is chosen randomly and is not correlated with the independent variables. Besides, the term $u_{i}$ is not more time invariant in the sample.

The fourth method used for the analysis is the feasible generalized least square (FGLS). The sample used for our estimation is large enough, so that the FGLS estimator is not biased as could be in small sample.

\section{Results}

Table 1 shows the results of our estimation. All four estimation methods proposed show the same significant variables. RE and FGLS display the best performance in terms of significance. EPL for regular workers (eplr) is statistically significant at the $10 \%$ only with FE method.

Looking at Table 1, we have: 1) the tax wedge (labortax) is significant with a positive coefficient. In this case, a reduction in the tax wedge produces a wage moderation from the supply side because part of the earnings lost can be recovered by the lower tax; 2) the union density (undens) is significant with a negative sign: strong union power does not lead to a rise in the wage-productivity gap. In order to evaluate this result, you can think that in many European countries unions do not only pursue the objective of increasing wages but they also pay attention to the productivity and others macroeconomics variables (for example, employment stability); 3) training for unemployed workers (almptrain) is significant with a negative coefficient. This kind of active labor market policy can thus reduce the component of the wage growth not explained by the productivity growth; 4) employment protection for temporary workers (eplt) affects negatively the WP gap. This result seems to confirm the one obtained by [4].

Passive labor market policies (unemployment benefits) and the strictness of 
regulation in the goods market do not seem to play a role in affecting the gap between wage and productivity growth.

\section{Conclusions}

In this paper we have analyzed from an empirical point of view the effects of some institutional factors (taxation, active and passive labor market policies, labor and goods market regulation and the unions' role during the wage bargaining) on the component of the wage growth not explained by the productivity growth. We have considered a Panel data related to 14 OECD countries over the period 1983-2003, using four different estimation methods.

Table 1. Estimation results.

\begin{tabular}{|c|c|c|c|c|}
\hline \multicolumn{5}{|c|}{ dependent variable: wage gap } \\
\hline & FEVD & $\mathrm{FE}$ & $\mathrm{RE}$ & FGLS \\
\hline \multirow[t]{2}{*}{ arr } & -0.0010 & -0.0010 & -0.0015 & -0.0015 \\
\hline & $(0.0025)$ & $(0.0025)$ & $(0.0023)$ & $(0.0022)$ \\
\hline \multirow[t]{2}{*}{$\mathrm{rr} 1$} & 0.0038 & 0.0038 & 0.0038 & 0.0038 \\
\hline & $(0.0085)$ & $(0.0058)$ & $(0.0057)$ & $(0.0055)$ \\
\hline \multirow[t]{2}{*}{ labortax } & $0.0152^{\star *}$ & $0.0107^{*}$ & $0.0151^{* * *}$ & $0.0151^{\star * *}$ \\
\hline & $(0.0061)$ & $(0.0058)$ & $(0.0059)$ & $(0.0057)$ \\
\hline \multirow[t]{2}{*}{ eplr } & 0.0093 & 0.0093 * & 0.0068 & 0.0068 \\
\hline & $(0.0083)$ & $(0.0053)$ & $(0.0053)$ & $(0.0051)$ \\
\hline \multirow[t]{2}{*}{ eplt } & $-0.0038^{*}$ & $-0.0038^{*}$ & $-0.0034^{*}$ & $-0.0034^{*}$ \\
\hline & $(0.0020)$ & $(0.0019)$ & $(0.0019)$ & $(0.0019)$ \\
\hline \multirow[t]{2}{*}{$\mathrm{pmr}$} & 0.0005 & 0.0005 & 0.0017 & 0.0017 \\
\hline & $(0.0045)$ & $(0.0039)$ & $(0.0039)$ & $(0.0037)$ \\
\hline \multirow[t]{2}{*}{ undens } & $-0.0158^{*}$ & $-0.0158^{* *}$ & $-0.0123^{\star *}$ & $-0.0123^{\star *}$ \\
\hline & $(0.0085)$ & $(0.0061)$ & $(0.0055)$ & $(0.0054)$ \\
\hline \multirow[t]{2}{*}{ almptrain } & $-0.0022^{* *}$ & $-0.0022^{* * *}$ & $-0.0026^{\star * *}$ & $-0.0026^{\star * *}$ \\
\hline & $(0.0009)$ & $(0.0008)$ & $(0.0008)$ & $(0.0008)$ \\
\hline \multirow[t]{2}{*}{ almyouth } & 0.0006 & 0.0006 & 0.0002 & 0.0002 \\
\hline & $(0.0006)$ & $(0.0006)$ & $(0.0006)$ & $(0.0005)$ \\
\hline \multirow[t]{2}{*}{ almpemp1 } & 0.0001 & 0.0001 & -0.0001 & -0.0001 \\
\hline & $(0.0006)$ & $(0.0006)$ & $(0.0006)$ & $(0.0006)$ \\
\hline \multirow[t]{2}{*}{ almppes } & 0.0002 & 0.0002 & 0.0007 & 0.0007 \\
\hline & $(0.0011)$ & $(0.0011)$ & $(0.0011)$ & $(0.0011)$ \\
\hline \multirow[t]{2}{*}{ uncovem } & 0.0009 & 0.0009 & 0.0005 & 0.0005 \\
\hline & $(0.0019)$ & $(0.0018)$ & $(0.0018)$ & $(0.0017)$ \\
\hline \multirow[t]{2}{*}{ constant } & 0.0121 & 0.0121 & 0.0122 & 0.0122 \\
\hline & $(0.0004)$ & $(0.0003)$ & $(0.0003)$ & $(0.0003)$ \\
\hline R-squared & 0.1430 & 0.1154 & 0.1284 & $0.0034^{\circ}$ \\
\hline & tabortax & & & \\
\hline
\end{tabular}

Value of $t$ statistics in brackets. ${ }^{*},{ }^{* *},{ }^{* *}$ statistically significant at the $10 \%, 5 \%$ and $1 \%$ levels, respectively. ${ }^{\circ}$ Value of Chi Square test. 
What emerges from the result of our analysis is that an economic policy based on training for unemployment workers and on the reduction of the tax wedge can reduce the WP gap. Union density and employment protection for temporary workers can also play a role to reach this objective.

In this sense, this paper suggests a clear hierarchy of priorities for the economic policy to bring the wage growth in line with the productivity growth.

\section{Acknowledgements}

We wish to thank William Addessi, Enrico Marchetti, Francesco Patriarca, Antonio Scialà, Massimiliano Tancioni and all the participants to the XXX Conference of Labour Economics (Cagliari, September 2015) for useful comments and suggestions. The usual disclaimers apply.

\section{References}

[1] Nicoletti, G. and Scarpetta, S. (2003) Regulation, Productivity and Growth. Economic Policy, 37, 11-76. https://doi.org/10.1787/078677503357

[2] Amable, B. (2009) Structural Reforms in Europe and the (in) Coherence of Institutions. Oxford Review of Economic Policy, 25, 17-39.

https://doi.org/10.1093/oxrep/grp001

[3] Bassanini, A., Nunziata, L. and Venn, D. (2009) Job Protection Legislation and Productivity Growth in OECD Countries. Economic Policy, 24, 349-402. https://doi.org/10.1111/j.1468-0327.2009.00221.x

[4] Lopez-Villavicencio, A. and Silva, J.I. (2011) Employment Protection and the Non-Linear Relationship between the Wage-Productivity Gap and Unemployment. Scottish Journal of Political Economy, 58, 200-220.

https://doi.org/10.1111/j.1467-9485.2011.00543.x

[5] Cette, G., Lopez, J. and Mairesse, J. (2016) Market Regulations, Prices, and Productivity. American Economic Review: Papers \& Proceedings, 106, 104-108. https://doi.org/10.1257/aer.p20161025

[6] Millea, M. (2002) Disentangling the Wage-Productivity Relationship: Evidence from Select OECD Member Countries. International Advances in Economic Research, 8, 314-323. https://doi.org/10.1007/BF02295506

[7] Fuess, S. and Millea, M. (2006) Pay and Productivity in "Corporatist" Germany. Journal of Labor Research, 27, 397-409. https://doi.org/10.1007/s12122-006-1030-z

[8] Blanchard, O.J. and Giavazzi, F. (2003) Macroeconomic Effects of Regulation and Deregulation in Goods and Labor Markets. The Quarterly Journal of Economics, 118, 879-907. https://doi.org/10.1162/00335530360698450

[9] Bassanini, A. and Duvall, R. (2006) Employment Patterns in OECD Countries: Reassessing the Role of Policies and Institutions. OECD Economics Department Working Paper 486.

[10] Plümper, T. and Tröger, V. (2004) The Estimation of Time-Invariant Variables in Panel Analyses with Unit Fixed Effects. SSRN Working Paper.

[11] Plümper, T. and Tröger, V. (2007) Efficient Estimation of Time-Invariant and Rarely Changing Variables in Finite Sample Panel Analyses with Unit Fixed Effects. Political Analysis, 15, 124-139. https://doi.org/10.1093/pan/mpm002

[12] Amable, B., Demmou, L. and Gatti, D. (2007) Employment Performance and Institutions: New Answers to an Old Question. IZA Discussion Papers 2731. 
[13] Kang, W. and Ratti, R. (2013) Structural Oil Price Shocks and Policy Uncertainty. Economic Modelling, 35, 314-319. https://doi.org/10.1016/j.econmod.2013.07.025

[14] Inoue, A., Kuo, C.H. and Rossi, B. (2014) Identifying the Sources of Model Misspecification. CEPR Discussion Papers 10140. 


\section{Appendix: Description of the Independent Variables}

Average unemployment benefit replacement rate (arr):Average unemployment benefit replacement rate across two income situations (100\% and $67 \%$ of the average production worker earnings), three family situations (single, with dependent spouse, with spouse in work) and three different unemployment durations (first year; second and third years; fourth and fifth years of unemployment).

Initial (first year) unemployment benefit replacement rate (rr1): Average unemployment benefit replacement rate during the first year of unemployment across two income situations (100\% and $67 \%$ of the average production worker earnings) and three different family situations (single, with dependent spouse, with spouse in work).

Labor tax wedge (labortax): Tax wedge calculated following the National Accounts principles. It includes all the direct taxes, but excludes the social benefits.

Union density (undens): Share of workers affiliated to a trade union, in percentage of total employment.

Union coverage (uncovcm): Collective bargaining coverage rate, the share of workers covered by a collective agreement calculated as a percentage of total employment.

Public expenditures on active labor market policies: The public expenditures on active labor market policies per unemployed worker as a share of GDP per capita, in percentage. We have five main categories defined as follow: 1) labor market training (almptrain): Training for unemployed adults and those at risk, training for employed adults (youth and disabled people are excluded); 2) measures for youngpeople (almpyouth): special plans concerning measures for unemployed and disadvantaged youth, support of apprenticeship and related forms of general youth training; 3) subsidized employment (almpemp1): Targeted measures to promote or provide employment for the unemployed and other priority groups (youth and disabled people are excluded); 4) public employment services and administration (almppes): Placement, counseling and vocational guidance, job-search courses, assistance with displacement costs, administration of unemployment benefits, all other administration costs of labor market agencies including running labor market plans; 5) measures for disabled people (not considered in our estimation): Special plans about rehabilitation and project with the purpose to improve the employment of disabled people.

Employment protection legislation index (EPL): The OECD index measuring the strictness of employment protection legislation. The index varies from 0 to 6 and is built taking into account: a) the employment protection for regular workers against individual dismissals, in particular a1) difficulty in individual layoffs; a2) bureaucratic barriers that firms have to deal with in case of a worker's layoff; a3) measures to adopt in case of an advance notice. b) Specific requirements for collective dismissals. c) Regulation of temporary forms of employment. In our analysis, we consider two separate variables of EPL, that related to workers with permanent contracts (eplr) and that related to workers with temporary contracts (eplt). 
Product market regulation (pmr): The OECD index measuring the degree of rigidity in the product market. The PMR assumes a value from 0 to 6 and is computed with regard to seven sectors: gas, electricity, telecommunication, mail, air transport, railway transport, and freight transport. It is based on 18 indicators, which take into account: entry barriers, if the networks are privates or publics, integral vertical processes, prices control prices, duties customs, bureaucratic barriers, the presence of the public administration in the governance of firms in strategic sectors-like telecommunications-and the presence of the public administration as stockholder in firms which operate in the business sector.

Submit or recommend next manuscript to SCIRP and we will provide best service for you:

Accepting pre-submission inquiries through Email, Facebook, LinkedIn, Twitter, etc. A wide selection of journals (inclusive of 9 subjects, more than 200 journals)

Providing 24-hour high-quality service

User-friendly online submission system

Fair and swift peer-review system

Efficient typesetting and proofreading procedure

Display of the result of downloads and visits, as well as the number of cited articles Maximum dissemination of your research work

Submit your manuscript at: http://papersubmission.scirp.org/

Or contact me@scirp.org 